\title{
Changes in Sensory and Microbiological Quality Indices of Nile Tilapia (Oreochromis niloticus) and Grey Mullet (Mugil cephalus) During Ice Storage
}

\author{
Saadia, M. H. M. ${ }^{1}$, Khalil, M. K. M., Abdel-Nabey, A. A. and Abo Samaha, O. R.
}

\begin{abstract}
This study was carried out to determine quality changes of Nile tilapia (Oreochromis niloticus) and grey mullet (Mugil cephalus) stored in ice. Changes in sensory and microbiological attributes were evaluated during 16 and 14 day of storage for Nile tilapia and grey mullet, respectively. The overall sensory scores of both raw and steamed Nile tilapia and grey mullet gradually decreased with the ice storage. Highly significant correlation was found between the overall sensory scores of both raw and steam cooked Nile tilapia and grey mullet and storage time. The shelf life of Nile tilapia and grey mullet were 8 days in ice. The mesophilic aerobic bacterial count of Nile tilapia and flathead grey mullet flesh increased gradually during storage in ice from $2.38 \times 10^{3}$ and $7.67 \times 10^{2} \mathrm{CFU} / \mathrm{g}$ flesh to $4.10 \times 10^{4}$ and $2.13 \times 10^{4} \mathrm{CFU} / \mathrm{g}$ flesh after eight day of ice storage. The psychrophilic aerobic bacterial count increased gradually during storage in ice from $5.97 \times 10^{2}$ and $4.76 \times 10^{3} \mathrm{CFU} / \mathrm{g}$ flesh to $6.30 \times 10^{4}$ and $1.66 \times 10^{5} \mathrm{CFU} / \mathrm{g}$ flesh after eight day of ice storage. Psychrophiles had faster rate of increment during storage in ice, compared to mesophiles. Based on results of sensory evaluation the iced raw and steamed Nile tilapia and grey mullet samples could be classified into three categories of quality grade as follows :(1) high quality grade (stored in ice for not more than 4 days) (2) acceptable grade (stored in ice for more than 4 days, but less than 8 days), (3) unacceptable grade (stored in ice for more than 8 days).
\end{abstract}

Key words:- Sensory evaluation, Bacteriological evaluation, Nile tilapia, Grey mullet, Ice storage, Quality.

\section{INTRODUCTION}

Nowadays, there is an increasing demand for fish as an important source of food around the world (Silva et al., 2011). The share of fisheries production used for direct human consumption increased from about $70 \%$ in the 1980 s to more than $85 \%$ in 2012 (FAO, 2014). Egypt has one of the world's largest aquaculture sectors which makes a significant contribution to income, employment creation and food security. Animal foods provide important sources of energy, micro and macro nutrients but are commonly associated with food borne diseases. Livestock and fish value chains support the livelihoods of millions of rural and urban poor, for whom they can act as pathways out of poverty (ILRI, 2011).

The Nile tilapia, Oreochromis niloticus Linnaeus (Pisces: Cichlidae) is one of the most important fish species in the inland fisheries of tropical Africa, particularly in the Great East African rift valley lakes . Besides to its captured fisheries importance, Tilapia is one of the most important species for $21^{\text {st }}$ century aquaculture and is produced in more than 100 countries. Tilapias are now the second most popular farmed fishes after carps in the world (El-Sayed, 2006, Eknath et al., 2007, Yitayew, 2012 and moawad et al., 2017). The global production of farmed tilapia exceeded 2,002,087 metric ton (Yitayew, 2012). The average size (total length) of $O$. niloticus is $20 \mathrm{~cm}$ (FAO, 2012).

The most important producers of tilapia today are China, Egypt, Indonesia, and Philippines. The advantages of tilapia are its rapid growth, resistance to various diseases and stress, tolerance to changing environmental conditions, and willingness to spawn in captivity (Shoemaker et al., 2000). Illustrations from Egyptian tombs suggest that Nile tilapia were cultured more than 3,000 years ago (Popma and Masser, 1999).

Mullets are members of the Order Mugiliformes, Family Mugilidae. Mullets are ray-finned fish found worldwide in coastal temperate and tropical waters and, some species, in freshwater. Most species commonly reach about $20 \mathrm{~cm}$ total length, but some (e.g. Mugil cephalus) may attain $80-120 \mathrm{~cm}$. The head is broad and flattened dorsally in most species. The flathead grey mullet, Mugil cephalus, is a very important aquaculture species in the Mediterranean, Southeast Asia, Taiwan, Province of China, Japan and Hawaii (Saleh, 2008). Mullets are an important component of Egyptian fisheries and are considered as one of the most important cash crops from artisanal fisheries in the numerous lagoons throughout the country. The fish is commonly caught with gill, trammel and veranda nets by artisanal fishers operating in the sea, lakes and coastal lagoons (Saleh, 2008).

Iced storage is an important preservation method to maintain the quality and freshness of fish during handling and storage. Icing has been used widely to reduce undesirable biochemical and chemical reactions and to retard the growth of spoilage and pathogenic microorganisms. It is the cheapest and the most common

${ }^{1}$ Food Science and Technology Dept., Faculty of Agriculture, El-Shatby, Alexandria University, Alexandria, Egypt.

Received Augustb1, 2017, Accepted August 16, 2017 
and efficient preservative method utilized worldwide (Madrid and Philips, 2000).

Ice storage constitutes the first step, or at times, the only means of preserving fresh fish in Egypt in order to prevent and retard the lowering of freshness due to degradation of muscle protein which is a major reaction of the spoilage process in fish (Saltana, 2004).Efficient cooling with ice depends on the weight of fish, species, fish temperature, environmental temperature and the amount of ice (Bataringanya, 2007).Even during cold storage, whether using ice or refrigeration, the growth of spoilage microorganisms, and the chemical and enzymatic activity although slower, will over time lead to fish quality being diminished (Cakli et al., 2007). The shelf life of fish shelf life can be determined by physicochemical and microbiological analysis, as well as, sensory changes that occur in fish during the storage period have been commonly used (Massa et al., 2012, Borges et al., 2013 and Giuffrida et al., 2013).

Sensory assessment is the best way to evaluate the freshness and shelf life of fish as it is understandable by consumers and is indispensable for marketing (Joseph and Iyer, 2002) and (Sallam et al., 2007).However, sensory methods in general are known to be irrationally expensive due to the high training requirement of the panel; cost of running, need for individual scheme for individual fish species given the different spoilage patterns and physiological and psychological limitations of the analyst (Connell, 2001).

The major changes in fish freshness colour are largely due to bacterial activity. Microbiological methods are used to the freshness of fish, hygiene to detect presence of bacteria or organisms of public health importance (Dalgaard, 2002).

There are many factors affecting the initial microbial load and the storage time of food such as fish species, bacterial load, water temperature catching method, handling and storage conditions (Andrade et al., 2012, Chong et al., 2012 and Carracosa et al., 2014). The activity of microorganisms is the main factor limiting the shelf life of fresh fish. An estimation of the total viable counts (TVC) is used as an acceptability index in standards, guidelines and specifications (Olafsdottir et al., 1997).

There are little information regarding the storage life of Nile tilapia and grey mullet stored in ice in Egypt. Therefore, the present study was under taken to assessment shelf life and freshness of Nile tilapia and grey mullet during storage in ice at ambient temperature.

\section{MATERIALS AND METHODS}

\section{Materials:-}

The fresh Nile tilapia (Bolti) (Oreochromis niloticus) and grey mullet (Bouri) (Mugil cephalus) are utilized in the present study during 2015.

$15 \mathrm{~kg}$ of Nile tilapia (Oreochromis niloticus) were obtained from EL-Nozha Airport farm, Alexandria, while $15 \mathrm{~kg}$ of grey mullet (Mugil cephalus) were obtained from a private farm, Edkou, EL- Behera Governorate.

Fish samples were immediately transferred to the laboratory in the insulated boxes contained crushed ice for analysis (zero time). Nile tilapia had an average weight and length of $243.37 \mathrm{~g}$ and $21.03 \mathrm{~cm}$, while mullet had $309.8 \mathrm{~g}$ and $31.32 \mathrm{~cm}$, respectively.

Fish samples were mixed with crushed ice in layers form plastic containers of 1:2 (w/w) ratio. The plastic containers had holes at their bottoms for drainage the melted ice. The containers were held at an ambient temperature $(21 \pm 2 \mathrm{C})$. The fish samples were kept always covered with crushed ice during ice storage period by adding fresh ice to maintain the above mentioned ratio. Meanwhile, samples of fish were withdrawn at regular intervals $(2,4,6,8,10,12,14$ and 16 days of ice storage) for sensory and microbiological evaluation.

\section{Methods:-}

\section{Sensory evaluation}

Sensory evaluation of raw tilapia and mullet was performed by ten trained panelists chosen from the staff members of the Department of Food Science and Technology, Faculty of Agriculture, Alexandria University. The organoleptic assessment of raw tilapia and mullet were made according to the scale described by Barile et al. (1985). This scale ranged from zero (extremely unacceptable) to 10 (highly acceptable) for the following characteristics: acceptability, eye pupil, gills, body surface (appearance), odour, texture, flesh condition, viscera and belly wall.

Sensory evaluation of cooked tilapia and mullet samples was applied on $100 \mathrm{~g}$ flesh after steaming in lidded aluminum pan for $10 \mathrm{~min}$. The panelists were asked to score the organoleptic properties of the sample by giving scores ranged between 0 to 10 as described by Barile et al. (1985).

\section{Bacteriological analysis}

$10 \mathrm{~g}$ of flesh are transferred into $90 \mathrm{ml} 0.1 \%$ peptone water. From this dilution, other decimal dilutions were prepared. Total psychrophilic and mesophilic aerobic plate count were determined by the pour plating technique, using plate count agar (PCA) and the plates 
were inverted and incubated in an incubator at $35 \mathrm{C}$ for $48 \mathrm{~h}$ for mesophilic bacteria and at $7-10 \mathrm{C}$ for 10 days for psychrophilic bacteria (Bahmani et al., 2011).

Finally the number of colonies were counted and multiplied by dilution factor to calculate the total colonies forming units per g sample (Abelti, 2013).

\section{Statistical analysis}

Analysis of variance, regression and correlation were carried out according to Gomez and Gomez (1984) using SAS (Statistical Analysis System) ver.9.1, 2000.

\section{RERSULTS AND DISCUSSION}

\section{Sensory evaluation:}

\section{1. Sensory evaluation of Nile tilapia}

The data obtained from sensory evaluation of raw and steamed Nile tilapia (Oreochromis niloticus) during storage in ice at ambient temperature are presented in Table (1) and Fig. (1). The values were calculated as means of ten scoring evaluations during storage in ice.

There was a marked reduction in the sensory properties during ice storage. Storage of tilapia in ice usually concomitant with great changes in the appearance of raw Nile tilapia (Fig. 1). Body surface of fresh Nile tilapia was found to have a bright shining greenish blue colour immediately after catch, which progressively changed to a dull and slight grey when samples were attained the border of unacceptability. The colour of gills changed from bright red to pale dark red colour for the unacceptable samples. During storage of tilapia in ice, eyes appeared to progressively less crystalline and sunken. Flesh of tilapia, which was initially firm, became slightly soft on the unacceptability and at the end of the storage period, it converted into pasty and became easily separated from the bones. Belly wall was found to be bright firm and gradually changed to dull and digested as the time of storage proceeded.

Sensory panel score for odour, taste and texture of iced storage tilapia and after cooking in steam are presented in Table (1). The data indicated that the storage of Nile tilapia in ice had a noticeable effect on the reduction of taste scores, followed by the texture and odour of steamed cooked samples.

Results of sensory evaluation, as overall quality of raw and steamed Nile tilapia during storage in ice, are presented in Fig. (1). Fresh Nile tilapia taken immediately after catch possessed higher overall sensory scores ranged from 9 to 10 (out of 10) for both raw and steamed samples. Such scores decreased gradually with increasing the time of storage in ice. The results obtained in the present study are in a good agreement with those reported by Yasmine et al. (2001), Partiban et al. (2005), Adoga et al.( 2010), Liu et al. (2010),
Farag (2012), Reshika et al. (2013), Kapute et al. (2013), Abraham-Olukayode and Oramadike (2015) Goliat et al. (2016) and Rodrigues et al. (2016).

The shelf life of Nile tilapia stored in ice at ambient temperature was limited on the basis of the overall sensory scores as shown in Fig. (1). The overall sensory scores less than 5 points meant that Nile tilapia samples was organoleptically rejected. According to the overall sensory scores (Table 1 and Fig.1), the raw and steamed samples during storage in ice could be classified into three categories of quality grade as follows :(1) high quality grade (stored in ice for not more than 4 days) (2) acceptable grade (stored in ice for more than 4 days, but less than 8days) and (3) unacceptable grade (stored in ice for more than 8 days).

Based on sensory evaluation, Nile tilapia still acceptable for 8 days in ice storage at ambient temperature, where it became rejected after elapsing 8 days of storage in ice (Table 1).

The results obtained in the present study are in a general agreement with those of Partiban et al. (2005), Liu et al. (2010) and Farag (2012).

According to the results obtained by Yasmine et al. (2001) , Adoga et al. (2010), Kapute et al. (2013), Abraham-Olukayode and Oramadike (2015) Goliat et al. (2016) and Rodrigues et al. (2016) the shelf life of tilapia were higher than those found in the present study. On the other hand, Reshika et al. (2013) stated that shelf life of Nile tilapia stored in ice ranged between 3-5 days.

The longer shelf life of fresh fish stored in ice could be attributed to the low temperature resulted from ice that hinders microbial growth (Uchoi et al., 2011).

The acceptable storage life of each species is affected by many factors including, the catching method, the location of the fishing ground, the season of the year, the size of the fish, etc, (Lima dos Santos, 1981 and Andrade et al., 2015).

\section{2. Sensory evaluation of grey mullet}

Table (2) shows the sensory evaluation of raw and steamed grey mullet (Mugil cephalus) during ice storage at ambient temperature. The initial quality characteristics of raw flathead grey mullet were very high as it were, very bright appearance, elastic texture, bright and convex eyes and fresh odours.

The organoleptic scores decreased and the rejection of fish increased gradually with the time elapsed of storage (Fig. 2). The results obtained in the present study are in a good agreement with those reported by Özyurt et al. (2009), Bahmani et al. (2011) Reshika et al. (2013), Ninan and Zynudheen (2014) and Andrade et al. (2015). 


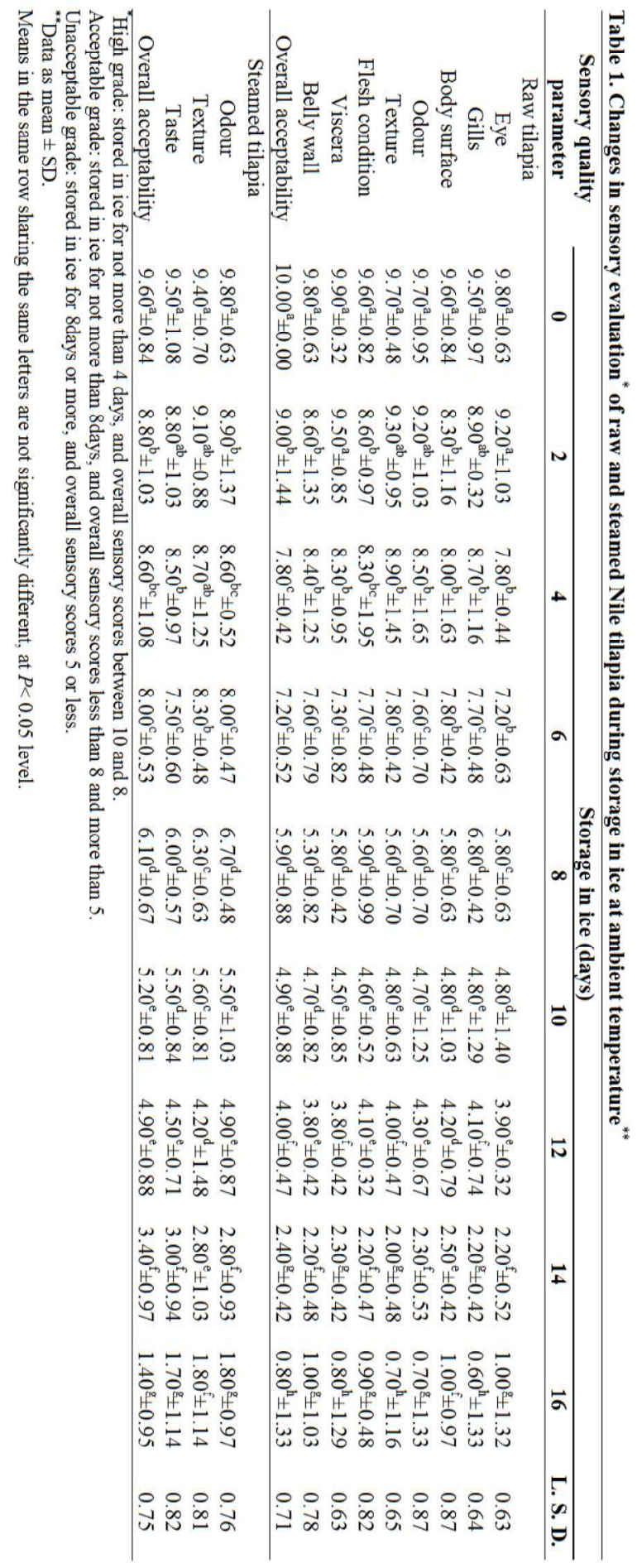




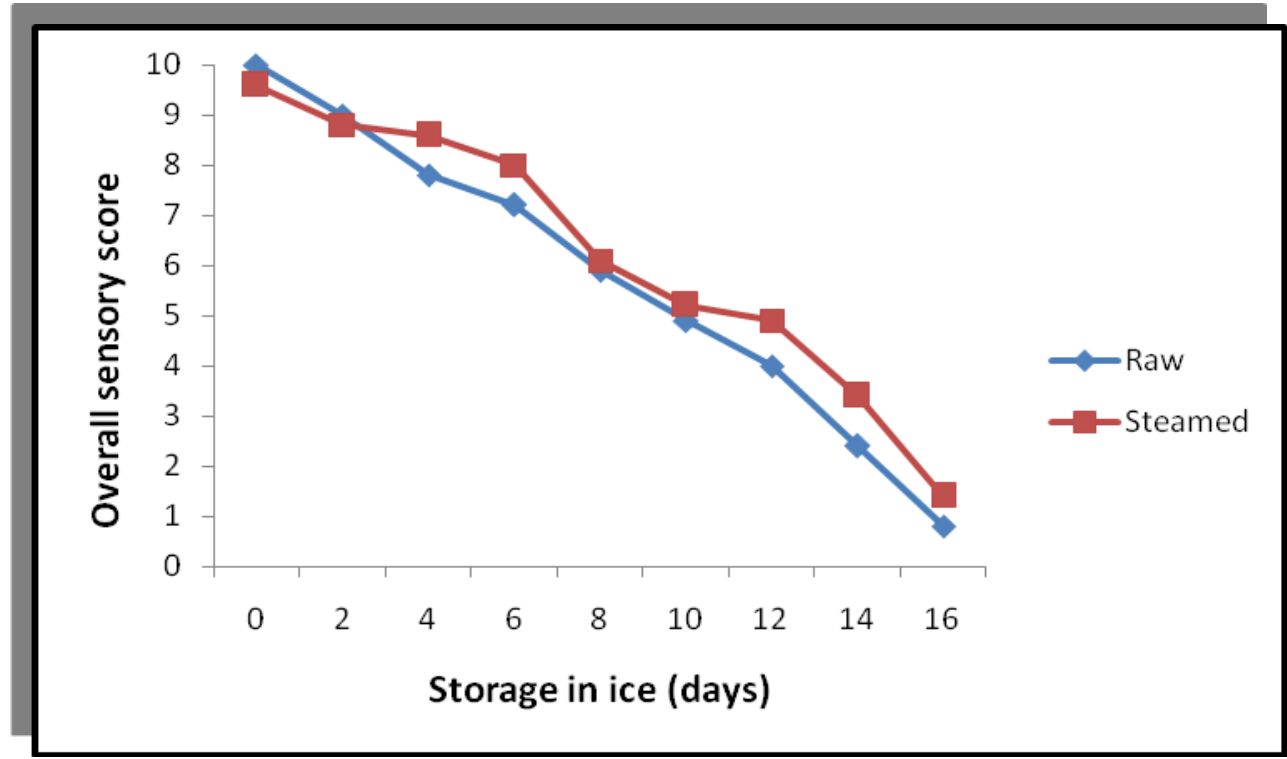

Fig. 1. Changes in sensory evaluation of raw and steamed Nile tilapia during storage in ice at ambient temperature

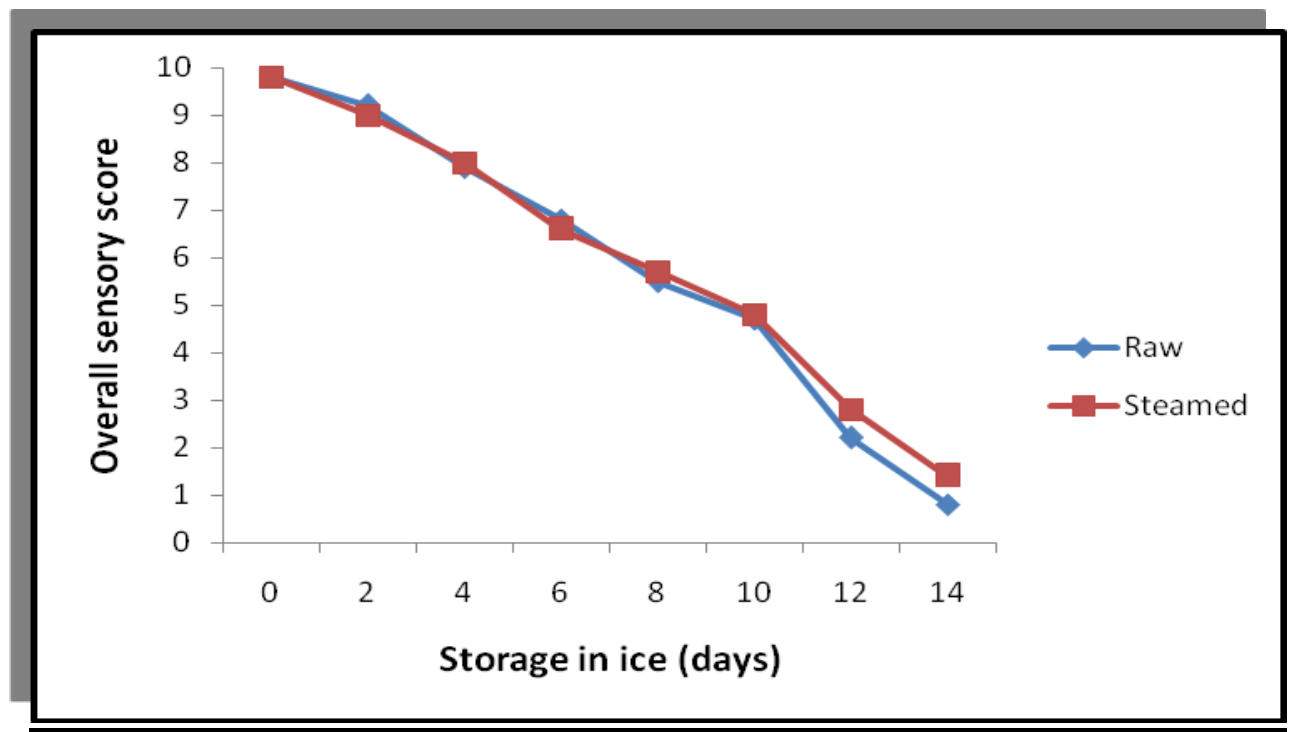

Fig. 2. Changes in sensory evaluation of raw and steamed flathead grey mullet during storage in ice at ambient temperature

The decrement of sensory scores was highly correlated with storage time Fig. (2), indicating quality deterioration. Fresh seaweedy odour, bright red firm texture and no-off odours were observed in fresh raw mullet as well as intense sweetness and meaty flavour were tasted in steamed samples.

Raw fish still in good quality and acceptable within 4-8 days of storage, after that, the quality was deteriorated.

The normal colour of the fresh fish may changed during storage and discolouration may occured. The pigments may have been oxidized or affected by some other factors. It is known that lipids convert to peroxides, aldehydes, ketones and lower aliphatic acids when they are oxidized (Sowicz et al., 2004). Although hydroperoxides are tasteless, they can brown and yellow colours in the fish tissue and gills (Bataringanya, 2007). Some browning also occurs in fatty fishes due to hydrolytic form reactions of fats and proteins (MANAGE, 2000).

As a result of prolong storage the texture of the muscle became more softer, eyes lose its concavity and scales became less adhered with the skin (Uchoi et al., 2011). 


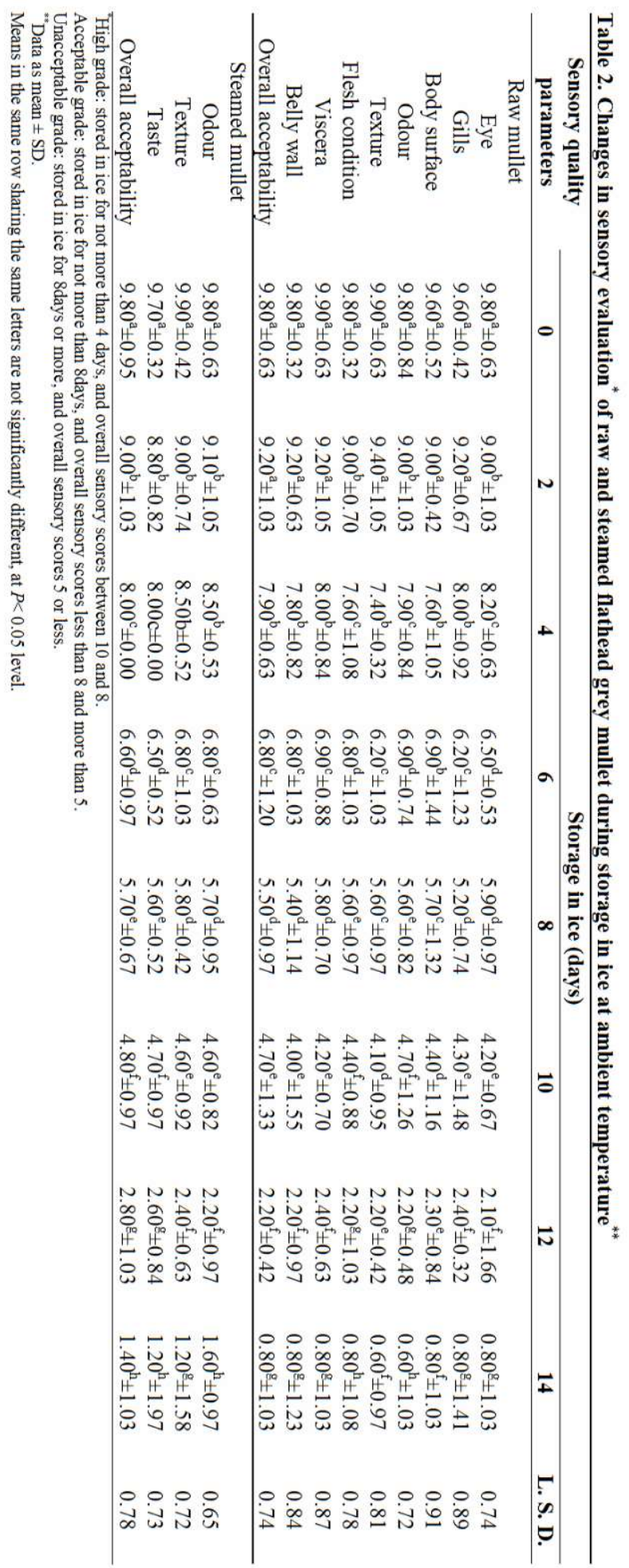


Similarly, all sensory characteristics of steamed samples (Table 2) had higher scores before 8 days, decreased gradually and became unacceptable on day 10 (Table 2).

The limit of acceptability for mullet was observed after 8 days while the lowest score was observed on day 14. This founding was close to the values reported by Özyurt et al. (2009), Bahmani et al. (2011) and Reshika et al. (2013).

On the other hand, the results of shelf life in the present study are in agreement with those reported by Ninan and Zynudheen (2014) and Andrade et al. (2015).

\section{Bacteriological evaluation:}

\section{1. Mesophilic and psychrophilic aerobic bacterial count of Nile tilapia}

The data presented in Table (3) show the changes in mesophilic and psychrophilic aerobic bacterial count (CFU/g flesh) of Nile tilapia (Oreochromis niloticus) during storage in ice at ambient temperature.

The increasing rate of mesophilic count was slower during the first 2 days of storage in ice, it was less than one logarithmic cycle, thereafter increased regularly till the end of storage period. There was significant difference $(P<0.05)$ between fresh samples (zero time) and iced storage samples (Table 3 ).

The mesophilic count increased gradually during ice storage from $2.38 \times 10^{3} \mathrm{CFU} / \mathrm{g}$ flesh at zero time to $4.10 \times 10^{4} \mathrm{CFU} / \mathrm{g}$ flesh at the eighth day of iced storage, where the samples organoleptically rejected (Table 3 ).

As it can be seen from Table (3), the pattern of changes in psychrophilic bacterial count in Nile tilapia flesh was similar as in mesophilic bacterial count. The psychrophilic bacterial count tended to gradually increase throughout the iced storage period. The initial level of psychrophiles (zero time) was $5.97 \times 10^{2} \mathrm{CFU} / \mathrm{g}$ flesh and increased during iced storage up to $6.30 \times 10^{4}$ $\mathrm{CFU} / \mathrm{g}$ flesh after 8 days of storage, where the samples were unacceptable.

The results of the present study are in accordance with those a reported by Huss et al. (1997), Yasmin et al. (2001), Adoga (2010), Liu et al. (2010), Kulawik et al. (2013) Castillo-Yanez et al. (2014) and Rodrigues et al. (2016). They reported that the bacterial count of Nile tilapia flesh varied from $10^{2}-10^{3} \mathrm{CFU} / \mathrm{g}$ flesh and increased during storage in ice up to $10^{6}$ in the rejected samples.

The present results are not in accordance with those obtained by Abelti (2013) who reported that bacterial count was ranged from $6.33 \mathrm{CFU} / \mathrm{g}$ on day zero and $11.74 \mathrm{CFU} / \mathrm{g}$ on day 26 of storage in ice.

Variation in the initial bacterial load could be ascribed to the microbial load of the waters in which they live (Huss, 1988). The eventual increase observed in mean total plate count could be due to multiplication of organisms favored at the storage condition (Ibrahim and El -Sherif, 2008).

High significant correlation coefficient was found between mesophilic bacterial count and sensory evaluation $\left(\mathrm{R}^{2}=-0.82\right)$ during iced storage period, which not observed in psychrophilic bacteria $\left(\mathrm{R}^{2}=\right.$ 0.62).

A significant positive regression coefficient was obtained between storage days and mesophilic bacterial count in Nile tilapia samples $\left(\mathrm{R}^{2}=+0.59\right)$ (Fig. 3), which not observed in psychrophilic bacteria $\left(\mathrm{R}^{2}=+0.30\right)$ (Fig. 4).

The present study indicated that the initial psychrophilic bacterial count of fresh Nile tilapia at zero time $\left(5.97 \times 10^{2} \mathrm{CFU} / \mathrm{g}\right.$ flesh) was lower than that of mesophilic bacterial count $\left(2.38 \times 10^{3} \mathrm{CFU} / \mathrm{g}\right.$ flesh) by one logarithmic cycle (Table 3). Although the increase in psychrophilic bacterial count was parallel to the increase in mesophilic bacterial count, but the increasing rate of the psychrophiles faster during the iced storage period. These results agreed was with the results reported by Liu et al. (2010). Therefore, the rejection levels of both in mesophilic and psychrophilic aerobic bacterial count at the eighth day of storage in ice were closely the same $4.10 \times 10^{4}$ and $6.30 \times 10^{4} \mathrm{CFU} / \mathrm{g}$ flesh, respectively.

The mesophilic and psychrophilic aerobic bacterial count of Nile tilapia samples at the eighth day of storage in ice, when Nile tilapia was unacceptable according to sensory evaluation $\left(4.10 \times 10^{4}\right.$ and $6.30 \times 10^{4} \mathrm{CFU} / \mathrm{g}$ flesh, respectively). This level agreed greatly with the recommendations set by ICMSF (1986), IFST (1999) and EOS (2005) which claimed that the maximum bacterial limit for fresh never exceeds the $10^{6} \mathrm{CFU} / \mathrm{g}$ flesh.

It could be concluded that the initial load of mesophilic bacteria was tenfold psychrophilic bacterial load. The mesophilic bacteria were easily adapted to growth at iced storage temperature, also, the psychrophilic bacteria had faster increasing rate during the iced storage compared with mesphiles. The above mentioned results may help in explaining the shorter shelf life of the examined tilapia samples. This conclusion agreed well with what was previously reported by Liu et al. (2010). 
Table 3. Changes in mesophilic and psychrophilic aerobic bacterial count (CFU"/ $\mathrm{g}$ flesh) of Nile tilapia during storage in ice at ambient temperature

\begin{tabular}{lcc}
\hline Storage in ice (days) & Mesophilic & Psychrophilic \\
\hline 0 & $2.38 \times 10^{3 \mathrm{c}} \pm 8.04 \times 10^{2}$ & $5.97 \times 10^{2 \mathrm{~d}} \pm 1.16 \times 10^{2}$ \\
2 & $5.72 \times 10^{3 \mathrm{c}} \pm 8.00 \times 10^{2}$ & $1.72 \times 10^{3 \mathrm{~d}} \pm 3.70 \times 10^{2}$ \\
4 & $1.16 \times 10^{4 \mathrm{c}} \pm 1.39 \times 10^{3}$ & $3.10 \times 10^{3 \mathrm{~d}} \pm 7.21 \times 10^{2}$ \\
6 & $2.43 \times 10^{4 \mathrm{c}} \pm 5.03 \times 10^{3}$ & $2.54 \times 10^{4 \mathrm{~d}} \pm 5.73 \times 10^{3}$ \\
$8^{* * *}$ & $4.10 \times 10^{4 \mathrm{c}} \pm 7.21 \times 10^{3}$ & $6.30 \times 10^{4 \mathrm{~d}} \pm 1.20 \times 10^{4}$ \\
10 & $5.83 \times 10^{4 \mathrm{c}} \pm 6.03 \times 10^{3}$ & $2.00 \times 10^{5 \mathrm{~cd}} \pm 2.22 \times 10^{4}$ \\
12 & $8.37 \times 10^{4 \mathrm{c}} \pm 7.78 \times 10^{3}$ & $6.29 \times 10^{5 \mathrm{c}} \pm 1.22 \times 10^{5}$ \\
14 & $2.60 \times 10^{5 \mathrm{~b}} \pm 6.24 \times 10^{4}$ & $1.68 \times 10^{6 \mathrm{~b}} \pm 9.43 \times 10^{5}$ \\
16 & $6.23 \times 10^{5 \mathrm{a}} \pm 1.38 \times 10^{5}$ & $3.00 \times 10^{8 \mathrm{a}} \pm 0.00$ \\
L. S. D. & $9.08 \times 10^{4}$ & $5.38 \times 10^{5}$ \\
\hline CFU
\end{tabular}

*CFU Colony forming unit.

${ }^{* *}$ Data as mean $\pm \mathrm{SD}$.

*** Organoleptically unacceptable samples.

Means in the

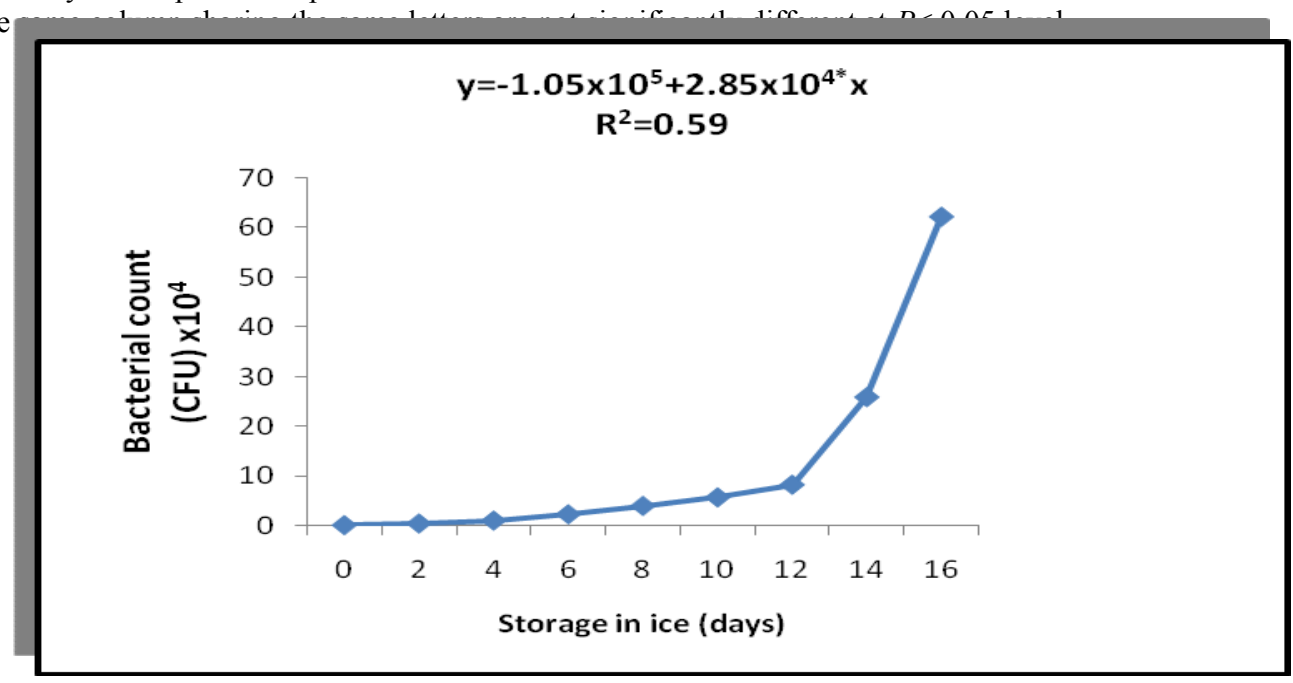

Fig. 3. Changes in mesophilic aerobic bacterial count (CFU / g flesh) of Nile tilapia during storage in ice at ambient ten

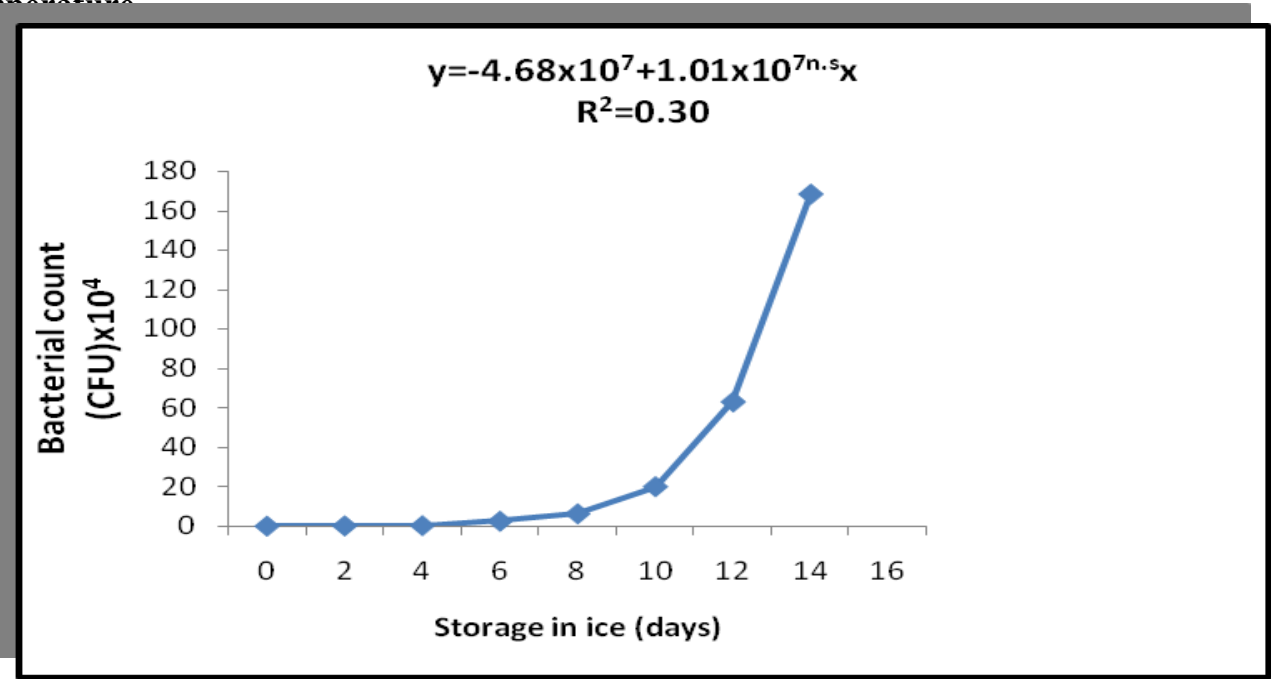

Fig. 4. Changes in psychrophilic aerobic bacterial count (CFU/g flesh) of Nile tilapia during storage in ice at ambient temperature 


\section{2. Mesophilic and psychrophilic aerobic bacterial count of grey mullet}

Changes in mesophilic and psychrophilic aerobic bacterial count (CFU/g flesh) of grey mullet (Mugil cephalus) during storage in ice at ambient temperature are shown in Table (4). The data obtained showed a significant difference $(P<0.05)$ between fresh samples (zero time) and iced samples.

In the present study, initial mesophilic and psychrophilic bacterial count of mullet flesh were 7.67 $\mathrm{x} 10^{2}$ and $4.76 \times 10^{3} \mathrm{CFU} / \mathrm{g}$, respectively. Mesophilic and psychrophilic counts reached $2.13 \times 10^{4} \mathrm{CFU} / \mathrm{g}$ and1.66 $\times 10^{5} \mathrm{CFU} / \mathrm{g}$ after 8 day of storage in ice. However, the initial microbial load and the storage time can be influenced by the fish species involved, bacterial load, type of bacteria present and the capture, handling and storing conditions (Huss (1995), Gram and Huss (1996), Andrade et al. ( 2012), Chong et al. (2012) and Carracosa et al. (2014).

Table 4. Changes in mesophilic and psychrophilic aerobic bacterial count (CFU*/g flesh) of grey mullet during storage in ice at ambient temperature

\begin{tabular}{ccc}
\hline Storage in ice (days) & Mesophilic & Psychrophilic \\
\hline 0 & $7.67 \times 10^{2 \mathrm{c}} \pm 2.30 \times 10^{2}$ & $4.76 \times 10^{3 \mathrm{c}} \pm 7.11 \times 10^{2}$ \\
2 & $1.38 \times 10^{3 \mathrm{c}} \pm 1.10 \times 10^{2}$ & $1.39 \times 10^{4 \mathrm{c}} \pm 3.30 \times 10^{3}$ \\
4 & $4.99 \times 10^{3 \mathrm{c}} \pm 6.00 \times 10^{2}$ & $3.24 \times 10^{4 \mathrm{c}} \pm 1.81 \times 10^{4}$ \\
6 & $1.13 \times 10^{4 \mathrm{c}} \pm 1.97 \times 10^{3}$ & $7.67 \times 10^{4 \mathrm{c}} \pm 1.35 \times 10^{4}$ \\
$8^{* * *}$ & $2.13 \times 10^{4 \mathrm{c}} \pm 3.52 \times 10^{3}$ & $1.66 \times 10^{5 \mathrm{c}} \pm 9.88 \times 10^{4}$ \\
10 & $4.40 \times 10^{4 \mathrm{c}} \pm 1.45 \times 10^{4}$ & $6.20 \times 10^{5 \mathrm{bc}} \pm 1.95 \times 10^{5}$ \\
12 & $1.08 \times 10^{5 \mathrm{~b}} \pm 2.03 \times 10^{4}$ & $3.44 \times 10^{6 \mathrm{~b}} \pm 9.42 \times 10^{4}$ \\
14 & $3.52 \times 10^{5 \mathrm{a}} \pm 7.65 \times 10^{4}$ & $3.00 \times 10^{8 \mathrm{a}} \pm 0.00$ \\
L. S. D. & $4.80 \times 10^{4}$ & $9.86 \times 10^{5}$ \\
\hline
\end{tabular}

${ }^{*} \mathrm{CFU}$ Colony forming unit.

${ }^{* *}$ Data as mean \pm SD.

${ }^{* * *}$ Organoleptically unacceptable samples.

Means in the same column sharing the same letters are not significantly different at $P<0.05$ level.

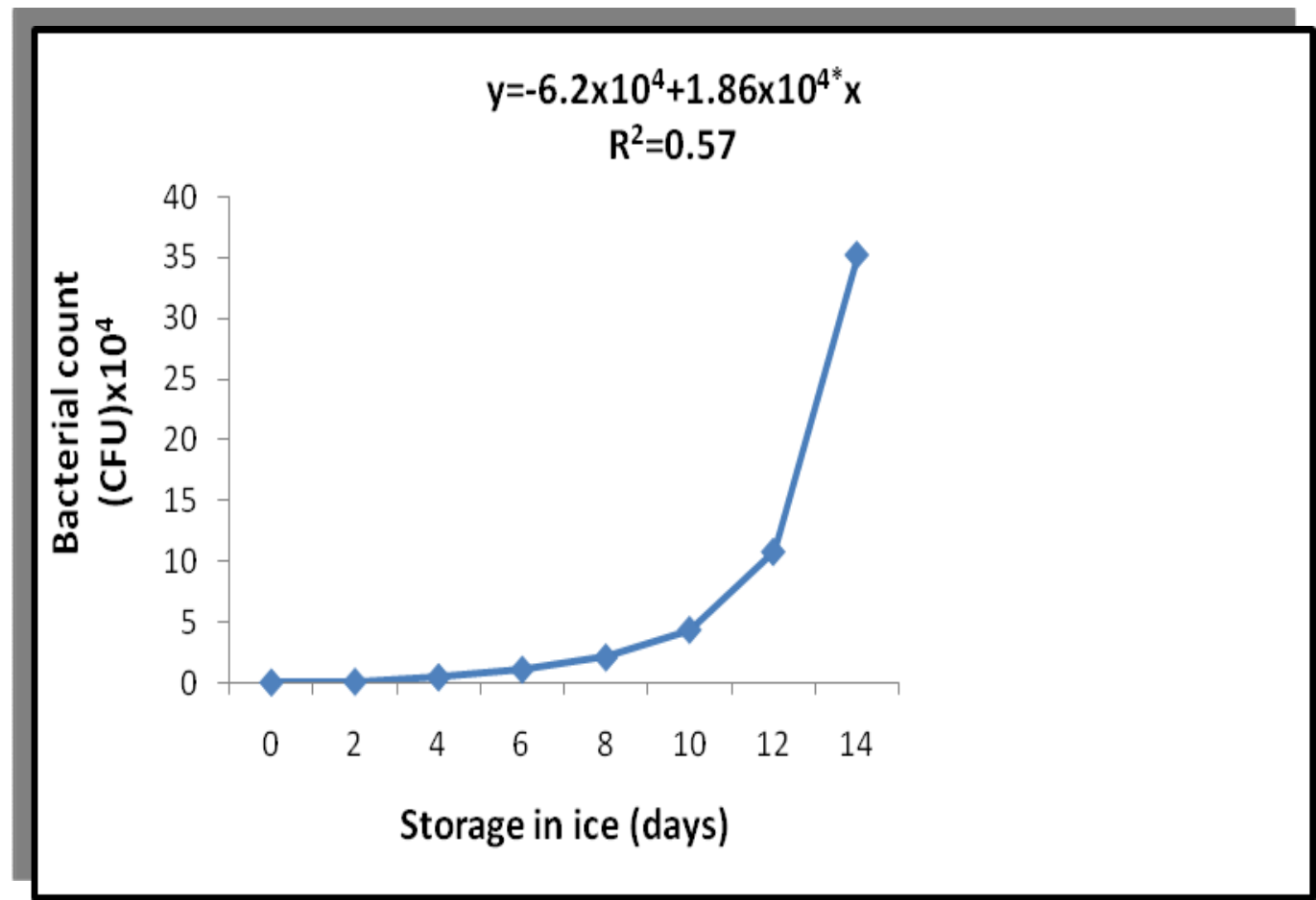

Fig. 5. Changes in mesophilic aerobic bacterial count (CFU/g flesh) of grey mullet during storage in ice at ambient temperature 


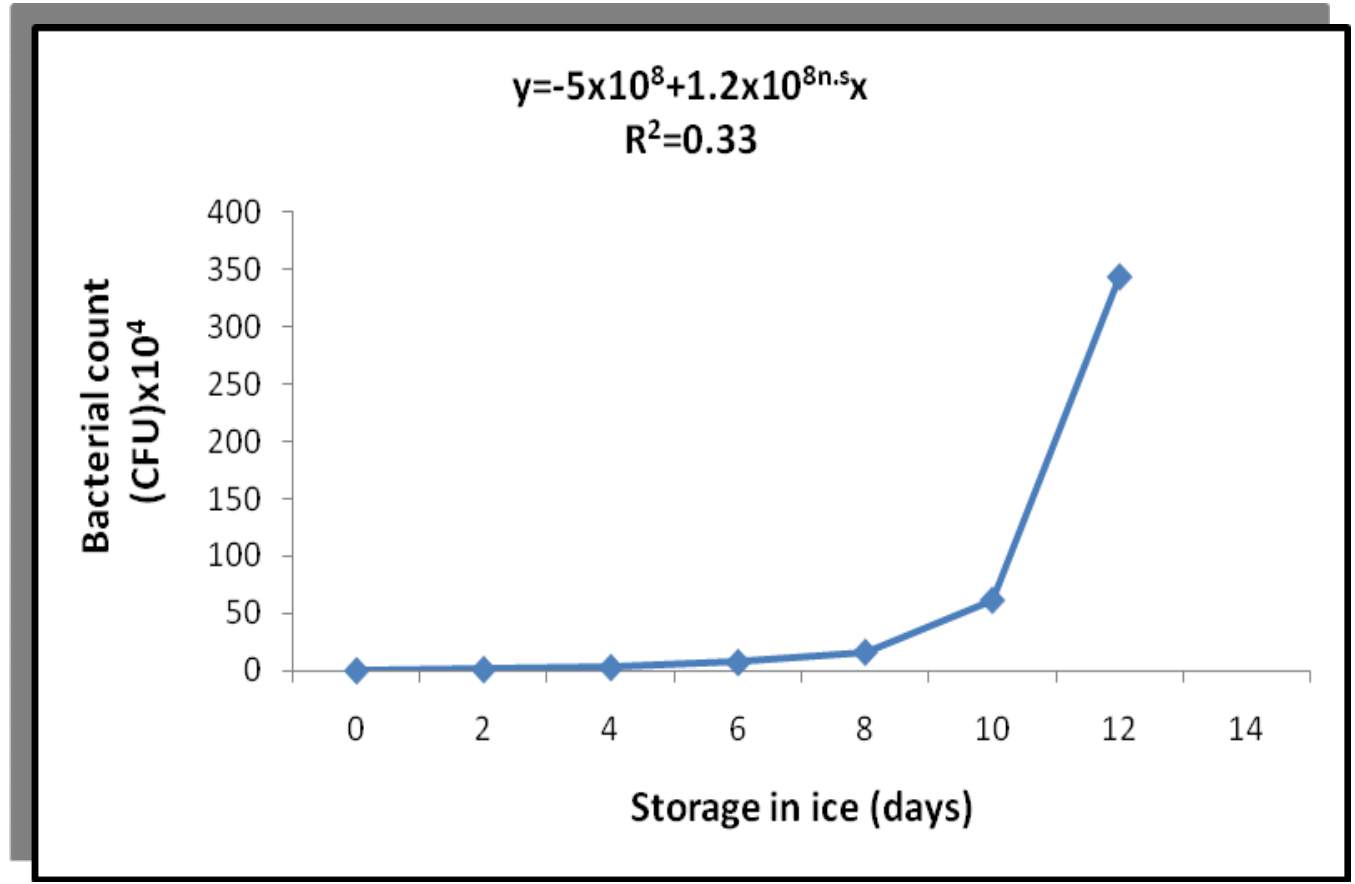

Fig. 6. Changes in psychrophilic aerobic bacterial count (CFU/g flesh) of grey mullet during storage in ice at ambient temperature

It can be noted that the total bacterial population increased sharply (Fig. 5 and 6) and reached $3.52 \times 10^{5}$ and $3.00 \times 10^{8} \mathrm{CFU} / \mathrm{g}$ flesh for mesophilic and psychrophilic bacterial count, respectively at the end of storage.

The results obtained in the present study are in a good agreement with those reported by Özyurt et al. (2009), Bahmani et al. (2011) and Andrade et al. (2014).

A significant negative correlation coefficient was observed between the mesophilic bacterial count and sensory evaluation $\left(\mathrm{R}^{2}=0.82\right)$, which not observed for psychrophilic bacterial count and sensory evaluation $\left(\mathrm{R}^{2}=-0.64\right)$. A significant regression coefficient was observed between the mesophiles count and the iced storage time $\left(\mathrm{R}^{2}=0.57\right)$, which not observed for psychrophilic count $\left(\mathrm{R}^{2}=0.33\right)$.

At the eighth day of storage in ice, mullet samples still had high quality considering that the microbiological upper limit for fresh fish proposed by ICMSF (1986), IFST (1999) and EOS (2005) not exceed $10^{6} \mathrm{CFU} / \mathrm{g}$ flesh. The values finally rose to an unacceptable value at the end of 14 days storage period.

\section{REFERENCES}

Abelti, A. L. 2013. Microbiological and chemical changes of Nile tilapia (Oreochromis niloticus L.) fillet during ice storage: Effect of age and sex Advance. Journal of Food Science and Technology, 5: $1260-1265$.
Abraham-Olukayode, A. O. and C. E. Oramadike. 2015. Shelf life studies of wild tilapia (Tilapia guineensis) stored in ice and at ambient temperature. American Journal of Agricultural Science, 2: 8-12.

Adoga, I. J., E. Joseph and O. F. Samuel. 2010. Storage life of tilapia (Oreochromis niloticus) in ice and ambient temperature. National Institute for freshwater Fisheries Research (NIFFR), 5: 39-44.

Andrade, S. C. S., E. T. Marsico, R. M. Franco, R. L. O. Godoy, S. Pacheco; M.F. Queiroz and C. F. M. Guimaraes. 2012. Shelf life of chilled and whole sardines evaluated by physical-chemical, bacteriological and sensory. Ciênc. Rural, 42: 1901-1907.

Andrade, S. C. S., E. T. Marsico, R. L. O. Godoy, R. M. Franco, and C. A. C. Junior. 2014. Chemical quality indices for freshness evaluation of fish. Journal of Food Studies, 3:71-87.

Andrade, S. C. S., E. T. Marsico, R. M. Franco, S. B. Mano, C. A. Conte, M. Q. Freitas and A. G. Cruz. 2015. Effect of storage temperature at the quality index method scheme and shelf life study of mullet (Mugil planus). Journal of Food Quality, 38: 60-70.

Bahmani, Z. A ., M. Rezai, S. V.Hosseini, J. M. Regenstein; K. Böhme, A. Alishahi and F. Yadollahi. 2011. Chilled storage of golden gray mullet (Liza aurata). Food Science and Technology, 44: $1894-1900$.

Barile, L. E., A. D. Milla, A. Reilly and A. Villadsen. 1985. Spoilage patterns of Mackerel (Rastrielliger faughnimatsui)- mesophilic and psychrophilic spoilage. FAO Fisheries Research, 317:146-154. 
Bataringanya, A. 2007. Analysis of quality deterioration at critical steps points in Fish handling in Uganda and Iceland and suggestions for improvement. Project Report. United Nations Fisheries Training Programme (UNU- FTP), Reykjavik, Iceland.

Borges, A., C.A. Conte-Juunior, R. M. Franco and M. Q. Freitas. 2013. Quality Index Method (QIM) developed for pacupiaractus mesopotamicus and determination of its shelf life. Food Res. Int., 54: 311-317.

Cakli, S., B. Kilinc, A. Cadun, T. Dincer and S. Tolasa. 2007. Quality differences of whole ungutted sea bream (Sparus aurata) and sea bass (Dicentrarchus labrax) while stored in ice. Food Control, 18: 391-397.

Carracosa, C., R. Millan, P. Saavedra, J. R. Jaber, T. Montenegro, A. Raposo, E. Perez and E. Sanjuan. 2014. Predictive models for bacterial growth in sea bass (Dicentrarchus labrax) stored in ice. Int. J. Food Sci. Technol., 49: 354-363.

Castillo-Yanez, F. J., E. I. Jimenez-Ruiz, D. F. CanizalesRodriguez, E. Marquez-Rios, S. Ruiz-Cruz and V.M. Ocaño- Higuera. 2014. Postmortem biochemical changes and evaluation of the freshness in the muscle of tilapia (Oreochromis niloticus) during storage in ice. Journal of Fisheries and Aquatic Science, 9:435-445.

Chong, C.Y., F. A. Bakar, R. A. Rahman, J. Bakar and M. Z. Zaman. 2012. Biogenic amine, amino acids and microflora changes in Indian mackerel (Rastrellinger kanagurta ) stored at ambient $(25-29 \mathrm{C})$ and ice temperature $\left(0^{\square}\right)$. J. Food Sci. Technol., 51:1118-1125.

Connell, J. J. 2001. Quality Control in Fish Industry. FAO Torry Research Station in partnership with Support Unit for International Fisheries and Aquatic Research, (SIFAR).

Dalgaard, P. 2002. Modelling and predicting the shelf life of seafood. In A. H. Bremne, (Ed.) Safety and quality issues in fish processing. Boca Raton Boston New York Washington, DC: Wood Head Publishing Limited, 191-219.

Eknath, A. E., H. B. Bentsen, R.W. Ponzoni, M. Rye, N. H. Nguyen, J. Thodesen and B. Gjerde. 2007. Genetic improvement of farmed tilapias: Composition and genetic parameters of a synthetic base population of Oreochromis niloticus for selective breeding. Aquaculture, 273: 1-14.

El-Sayed, A. M. 2006. Tilapia culture. UK: CABI Publishing, Wallingford. 294p.

EOS. 2005. Egyptian Organization for Standardization and Quality Control. Chilled Fish. ES: 3494: 1-12

FAO .2012. Cultured Aquatic Species Information Programme. Text by Rakocy, J. E. In: FAO Fisheries and Aquaculture Department [online]. Rome. [Cited 11 September 2012].

FAO. 2014. Web-based Reporting System for the Questionnaire on the Implementation of the Code of Conduct for responsible Fisheries. In: FAO Fisheries and Aquaculture Department[online]. Rome. [Cited 12 March 2014].
Farag, H. E. M. 2012. Sensory and chemical changes associated with microbial flora of Oreochromis niloticus stored in ice. International Food Research Journal, 19: 447-453.

Giuffrida, A., D. Valenti, F. Giarratana, G. Ziino, and A. Panebianco. 2013. A new approach to modeling the shelf life of Gilthead seabream ( Sparus aurata). International Journal of Food Science and Technology, 48: 1235-1242.

Goliat, C., F. Kapute and J. Valeta. 2016. Effect of prolonged storage in ice on nutrient composition and sensory quality of whole fresh pond raised tilapia fish (Oreochromis shiranus ). American Journal of Food and Nutrition, 4: 127-130.

Gomez, K. A. and Gomez, A. A. 1984. Statistical Procedures for Agricultural Research ( $2^{\text {nd }}$ ed.). John Wiley and Sons, New York.

Gram, L. and H. H. Huss. 1996. Microbial spoilage of fish and fish products. International Journal of Food Microbiology, $33: 121-137$

Huss, H. H. 1988. Fresh fish quality and quality changes. FAO/DANIDA. A Training Manual. FAO Fisheries Series No. 29.

Huss, H. H. 1995. Quality and quality changes in fresh fish. FAO Fisheries Technial Paper No.348, Food and Agriculture Organization (FAO) of the United Nations, Rome, Italy.

Huss, H. H., P. Dalgaard and L. Gram. 1997. Microbiology of fish and fish products. In: Seafood from Producer to Consumer, Integrated Approach to Quality. Luten, J.B., Børrosen, T. \& Oehlenschlager, J. (eds.), Elsevier Science, Amsterdam, The Netherlands, pp. 413-430.

Ibrahim, S. M. and S. A. El- Sherif. 2008. Effects of some plants extracts on quality aspects of frozen tilapia (Oreochrmis niloticus L.) fillet. Global Vet., 2: 62- 68.

IFST .1999. Development and use of microbiological criteria in foods. Institute of Food Science and Technology (UK). London.

ILRI .2011. CRP 3.7: More Meat, Milk and Fish by and for the Poor: Proposal. Nairobi: International Livestock Research Institute.

International Commission on Microbiological Specifications for Foods (ICMSF). 1986. Sampling plan and recommended microbiological limits for Seafood.

Joseph, J., and T. S. G. Iyer. 2002. Sensory evaluation. In K. Gopakumar (Ed.), Textbook of fish processing and technology (pp. 445: 467). New Delhi, India: IndianCouncil of Agricultural Research.

Kapute, F., J. Likongwe, J. Kangombe and C. Kiiyukia . 2013. Shelf life of whole fresh lake Malawi tilapia (Oreochromis species - Chambo) stored in ice. African Journal of Food, Agriculture, 13:7138-7156.

Kulawik, P., F. Özogul, and H. R Glew . 2013. Quality properties, fatty acids, and biogenic amines profile of fresh tilapia stored in ice. Journal of Food Science, 78: 10631086. 
Lima dos Santos, C. A. M. 1981. The storage of tropical fish in ice- A review. Trop. Sci., 23: 97- 123.

Liu, S., W. Fan, S. Zhong, C. Ma, P . Li, K. Zhou, Z. Peng and M. Zhu. (2010). Quality evaluation of tray-packed tilapia fillets stored at $0 \square \mathrm{C}$ based on sensory, microbiological, biochemical and physical attributes. African Journal of Biotechnology, 9: 692-701.

Madrid R. M .M. and H. Phillps .2000. Post-harvest handing and processing. In: freshwater prawn culture, the farming of Macrobrachium rosenbergii (M.B. New and W. C. Valent Eds.). Onsey Mead, Oxford, UK. 326-344.

MANAGE . 2008. National Institute of Agricultural Extension Management, Processing and Value Addition in Fisheries. Rajendranagar, Hyderabad, Andhra Pradesh, India.

Massa, A.E., E. Manca and M. I. Yeannes. 2012. Development of quality index method for anchovy (Engraulis anchoita) stored in ice: Assessment of its shelflife by chemical and sensory methods. Int. J. Food Sci. Technol., 18: 339-351.

Moawad, R. K., G. F. Mohamed, A. Hanna, G. F. Bareh and. K. F. Mahmoud. 2017. Assessment of hurdle technology to preserve Nile Tilapia fillets during refrigeration with the application of marjoram oil/polyphosphates dipping. Asian Journal of Scientific Research, 10: 116-127.

Ninan,G and A. A. Zynudheen. 2014. Evaluation of quality and shelf life of two commercially important fish species Viz., Tiger Tooth Croaker (Otolithes ruber Bloch and Schneider) and flathead grey mullet ( Mugil cephalus Linnaeus) in iced Conditions. Proc. Natl. Acad. Sci., India, Sect. Biol. Sci., 84:1035-1042.

Olafsdottir, G. E., J. Martinsdbttir, P. Oehlenschbger, B. Dalgaard, I. Jensen, I. M. Undeland, G. Mackie, J. Henehan and H. Nilsen. 1997. Methods to evaluate fish freshness in research and industry. Trends in Food Science and Technology, 8: 285-265.

Özyurt, G., E. Kuley, S. Özkütük and F. Özogul. 2009. Sensory, microbiological and chemical assessment of the freshness of red mullet (Mullus barbatus) and goldband goat fish (Upeneus moluccensis) during storage in ice. Food Chemistry, 11: 505 - 510 .

Partiban, F., T. U. Sankar, and R. Anandan. 2005. Changes in the functional properties of tilapia(Oreochromis mossambicus) protein during storage in ice. Fishery Technology ,42: 155-162.

Popma, T. and M. Masser. 1999. Tilapia: life history and biology. Southern Regional Aquaculture Center, United States Department of Agriculture, Texas A\&M University.
Reshika P., S. Sherry, D. Eseta and K. Azam. 2013. Shelf life of fish species collected from Suva (Fiji) fish market in immediate and delayed iced storage. J. Marine Sci. Res. Dev., 3.

Rodrigues, T. P., E. T. Mársico, R. M. Franco, S. C. R. Mello, I. C. Soares, N. O. C Zúniga and M .Queiroz de Freita. 2016. Quality index method (QIM) and quantitative descriptive analysis (QDA) of Nile tilapia (Oreochromis niloticus) quality indices. Afr. J. Agric. Res., 11: 209-216.

Saleh, M. 2008. Capture-based aquaculture of mullets in Egypt. In A. Lovatelli and P.F. Holthus (eds.). Capturebased aquaculture. Global overview. FAO Fisheries Technical Paper. No. 508. Rome, FAO. pp. 109-126.

Sallam, K. I., A. M. Ahmed, M. M. Elgazzar and E. A. Eldaly. 2007. Chemical quality and sensory attributes of marinated pacific saury ( Cololabis saira) during vacuum packaged storage at 4 C. Food Chem., 102: 1061- 1070.

Saltana, H. M. 2004. Effect of handling and storage treatments on ( $\square-3)$ fatty acids in some Egyptain fish, Ph.D. Thesis, Faculty of Agriculture, (Saba Basha) Alexandria University, Egypt.

Shoemaker, C. A., P. H. Klesius and J. J. Evans. 2000. Diseases of tilapia with empasison economically important pathogens. Proceedings of the $5^{\text {th }}$ International Symposium on tilapia Aquaculture.

Silva, T. M., P. S. Sabaini, W.P. Evangelista, B, A. Maria and M. B .A. Gloria. 2011. Occurrence of histamine in Brazilian fresh and canned tuna. Food Control, 22: 323327.

Sowicz, E. W., A. M. Gramza, Hêoe, H.H. Jeleñ, J. M. M. Korczak, Ecka; S. Mildner-szkudlarz, M. Rudziñska, U. Samotyja and R. Zawirska -wojtasiak. 2004. Oxidation of lipids in food. Polish Journal of Food and Nutrition Sciences, 13: 87-100.

Uchoi, D., S. C. Mandal, D.A. Barman, V. Kumar, A.J. Andrade and N. Phanna. 2011. Physical, chemical and microbial changes during chilled storage. Central Institute of Fisheries Education, Versova, Mumbai, India.

Yasmine, L., M. Kamal, K. M. Ahmed, M. N. Azinaddin and M. N. Islam M. N. 2001. Studied on the post morten changes in genetically improved farmed tilapia (Oreochromis niloticus) during ice storage. Pakistan. J. of Biological Sciences, 4: 114-1148.

Yitayew, T. 2012. The effect of storage temperature and time on bacteriological load and physicochemical quality of Nile tilapia (Oreochromis niloticus) fillet from Lake Tana, Ethiopia. M. Sc. Thesis, Addis Ababa University, Ethiopia. 


\section{الملخص العربي}

\section{التغيرات في مؤشرات الجودة الحسية والميكروبيولوجية للبلطى والبورى أثناء التخزين فى الثلج}

سعدية محمد هاشم محمد، محد خليل محمد خليل، على أحمد عبد النبى، أسامة راثد أبو سماحة ولئ

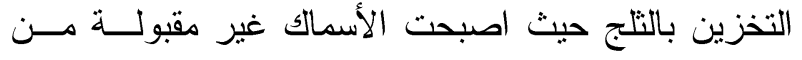

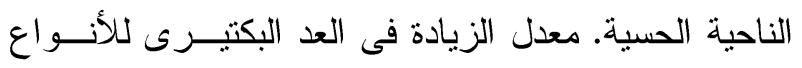

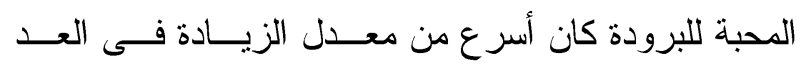

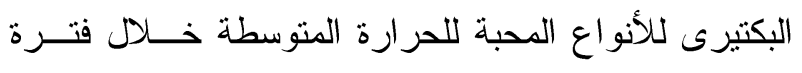

$$
\text { تخزين الاسماك بالتلج. }
$$

امكن تقسيم جودة أسماك البلطى و البورى بنــاءا علــى

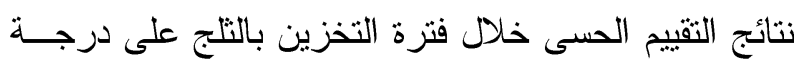

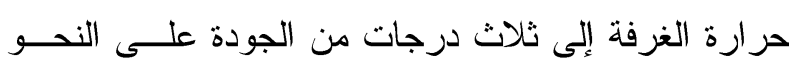
التالى:

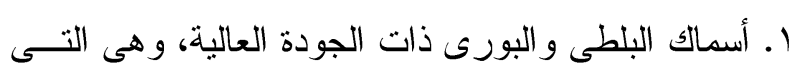
لم يمضى على تخزينها فى التلج أكثر من ؛ أبام.

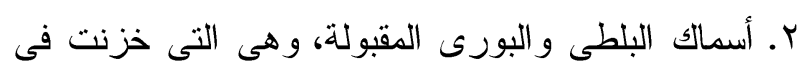
التلج أكثر من ع أيام و أقل من مأيام.

r. أسماك البلطى و البورى غير المقبولة، وهى التى خزنت فى التلج لمدة $\wedge$ أيام او أكثر.
الهدف من هذه الدراسة هو تقدير التغيرات فى خواص

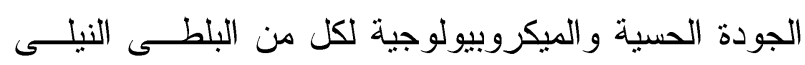

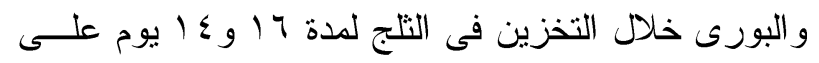

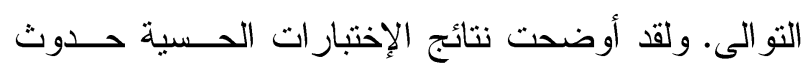
انخفاض تدريجى فى درجة التقبل العام لكل مــن البلطـى الإنى

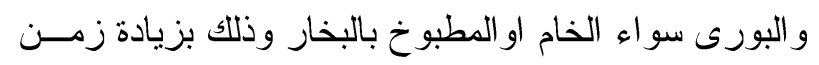
الحفظ بالتلاج. ولقد وجد أن الانخفاض فى درجة التقبل العام

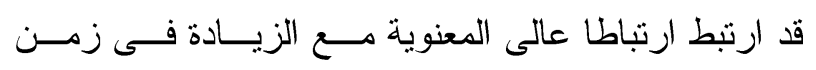

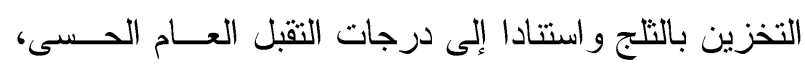

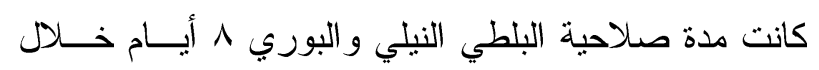
الحفظ بالثلج على درجة حرارة الغرفة. تبين وجود زيـادة

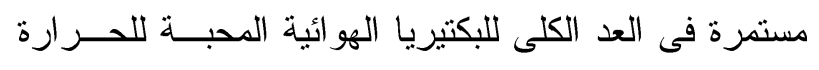

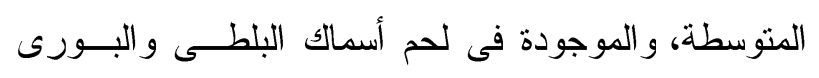

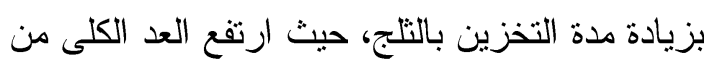

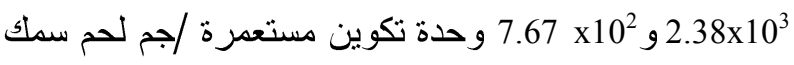
عند الزمن صفر من التخــزين الــى 2.13 x10 4.

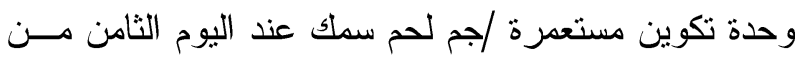

